Supplement of Earth Syst. Sci. Data, 14, 929-942, 2022

https://doi.org/10.5194/essd-14-929-2022-supplement

(C) Author(s) 2022. CC BY 4.0 License.

(c) (i)

Supplement of

\title{
Median bed-material sediment particle size across rivers in the contiguous US
}

Guta Wakbulcho Abeshu et al.

Correspondence to: Hong-Yi Li (hongyili.jadison@gmail.com) and Zhenduo Zhu (zhenduoz@buffalo.edu)

The copyright of individual parts of the supplement might differ from the article licence. 
a)

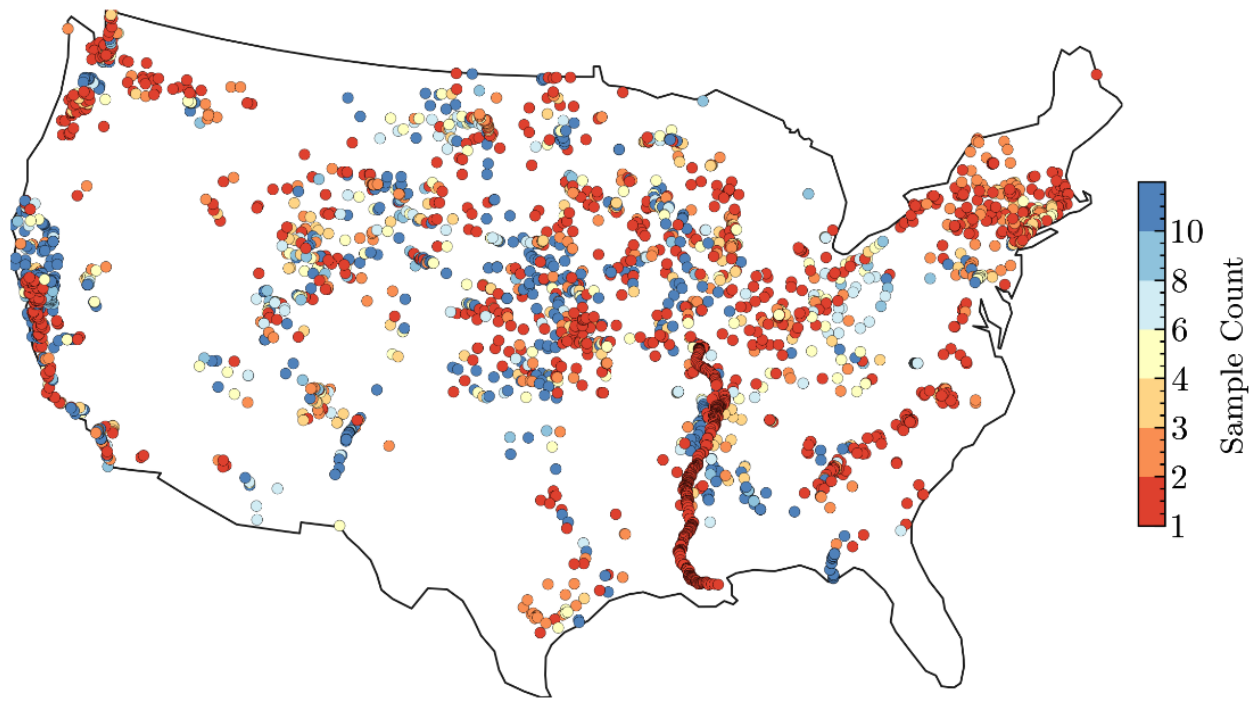

b)

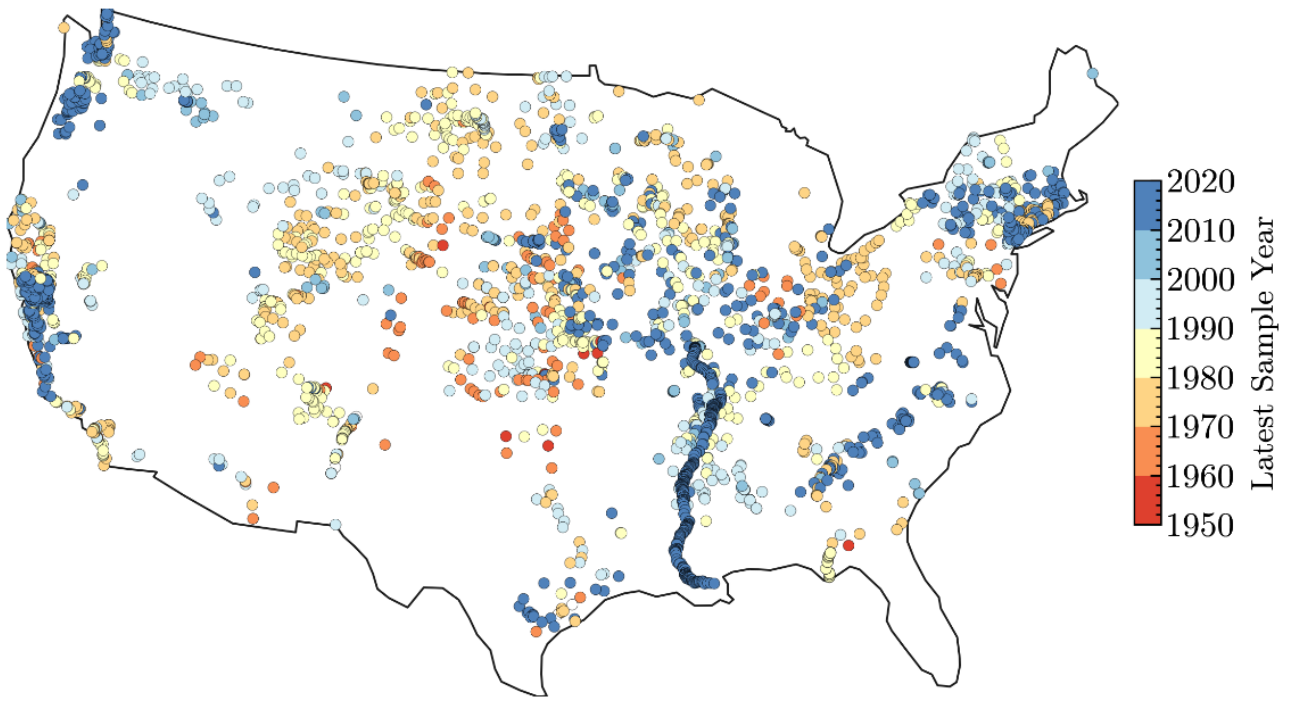

Figure S1: Spatial distribution of sample counts (a) and latest sampling year (b) of the 2577 sampling locations. 
a) Temporal Variablity $(\mathrm{n}=760)$

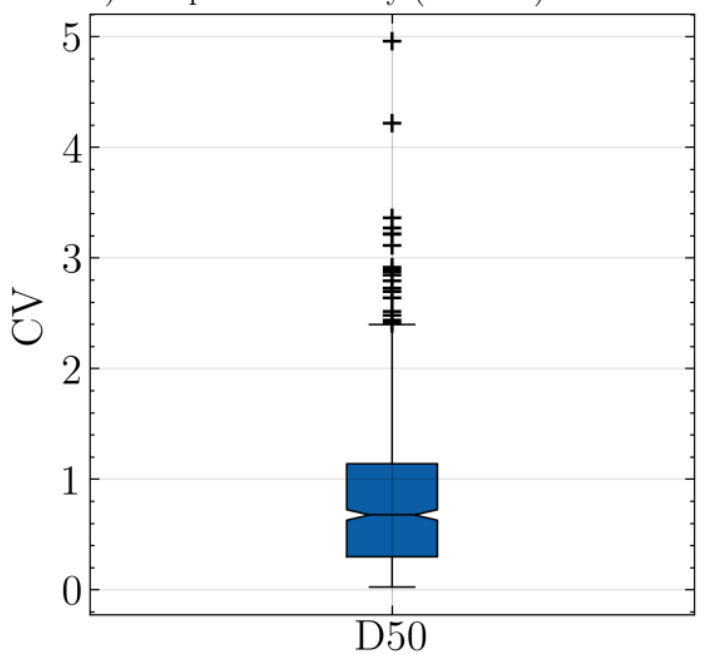

Figure S2: Distribution of the coefficient of variation (CV) for the 760 stations that have at least 5 samples over time. 

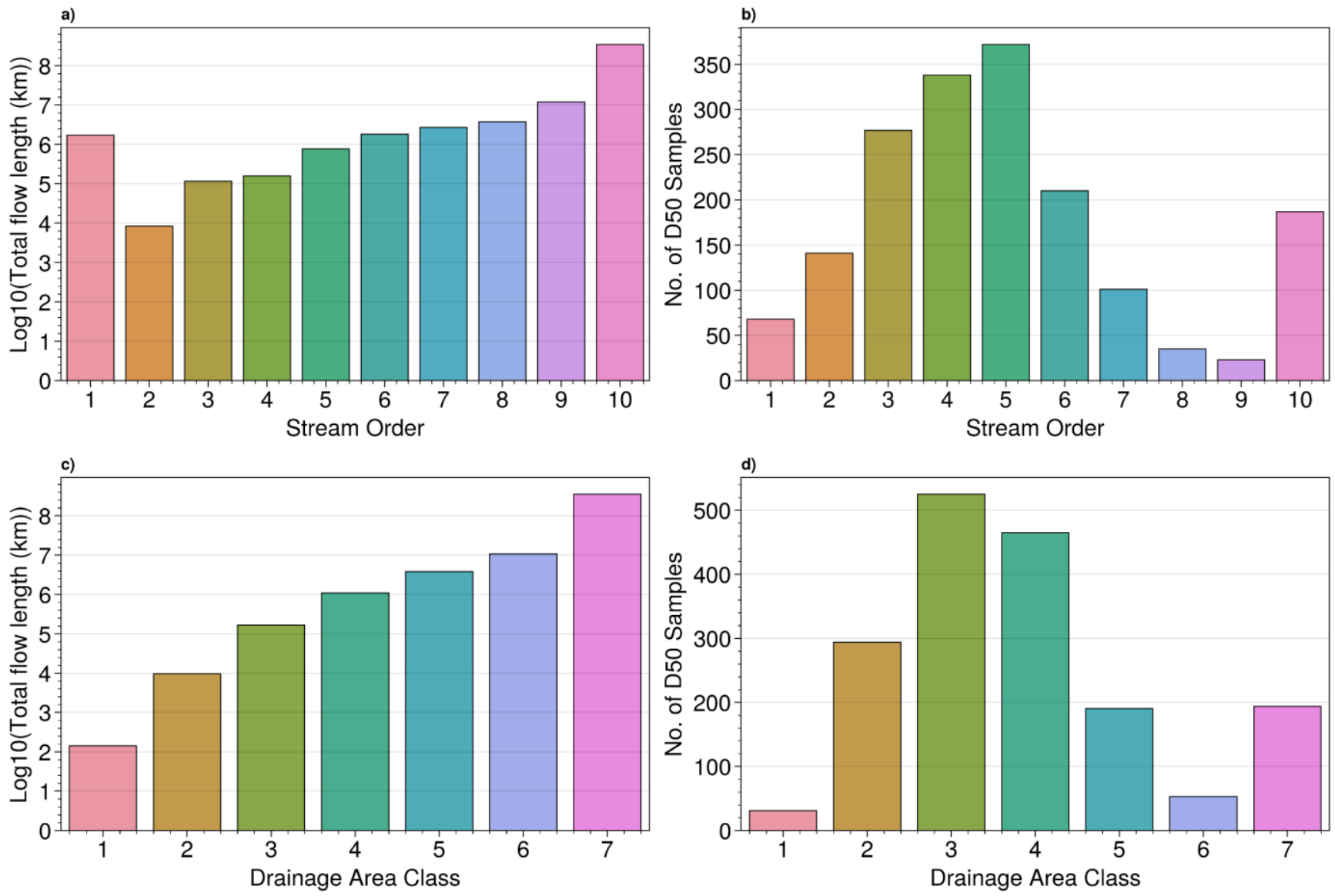

Figure S3: Distributions of total channel length $(a, c)$ and number of D50 samples $(b, d)$ within different classes of stream orders (a,b) and drainage areas (c,d). For Fig. 2 (c), (d), Drainage area class corresponds to categories of streams based on drainage areas, i.e., Class 1,<=10sqkm; Class 2, 10 100sqkm; Class 3, 100 1000sqkm; Class 4, 1000 1e+4sqkm; Class 5, 1e+4 1e+5sqkm; Class 6,1e5 1e+6sqkm; Class 7), > 1e+6sqkm. 

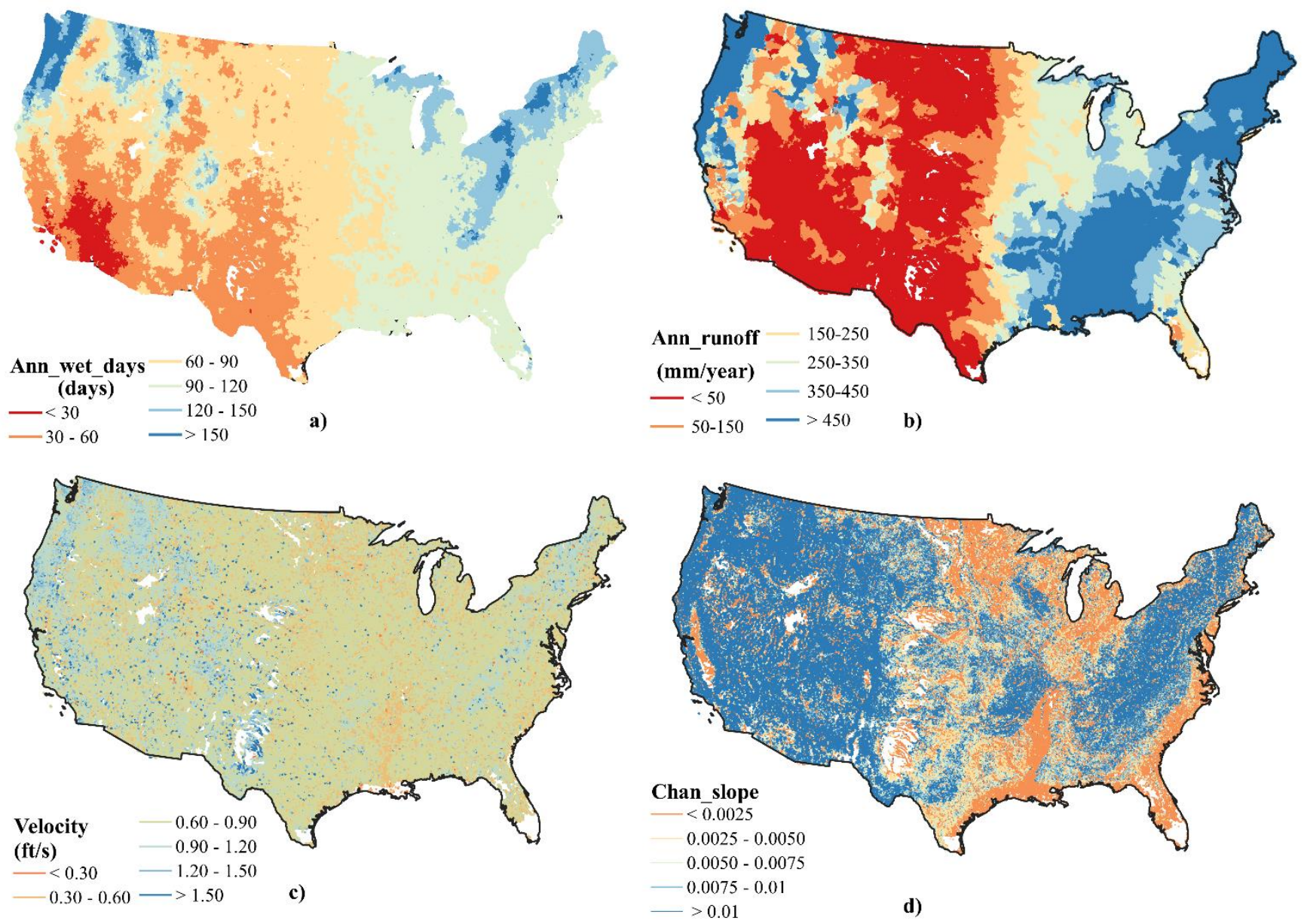

Figure S4: Spatial maps of predictive variables from NHDPlus. a. Annual average number of wet days (Ann_wet_days); $b$. Mean annual runoff (Ann_runoff); c. Mean annual flow velocity (Velocity); d. Slope of the flowline (Chan_slope). 
a)
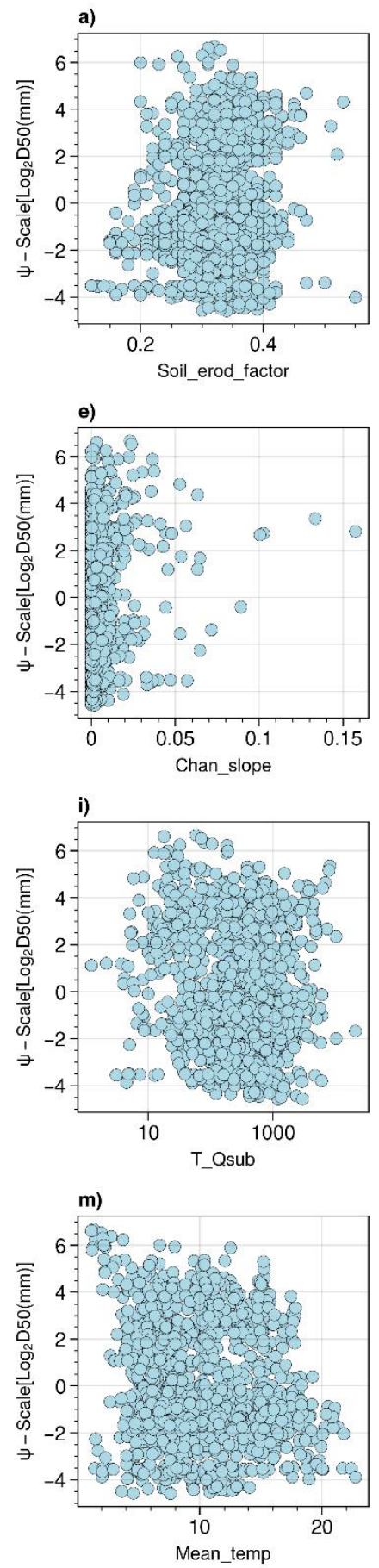

b)
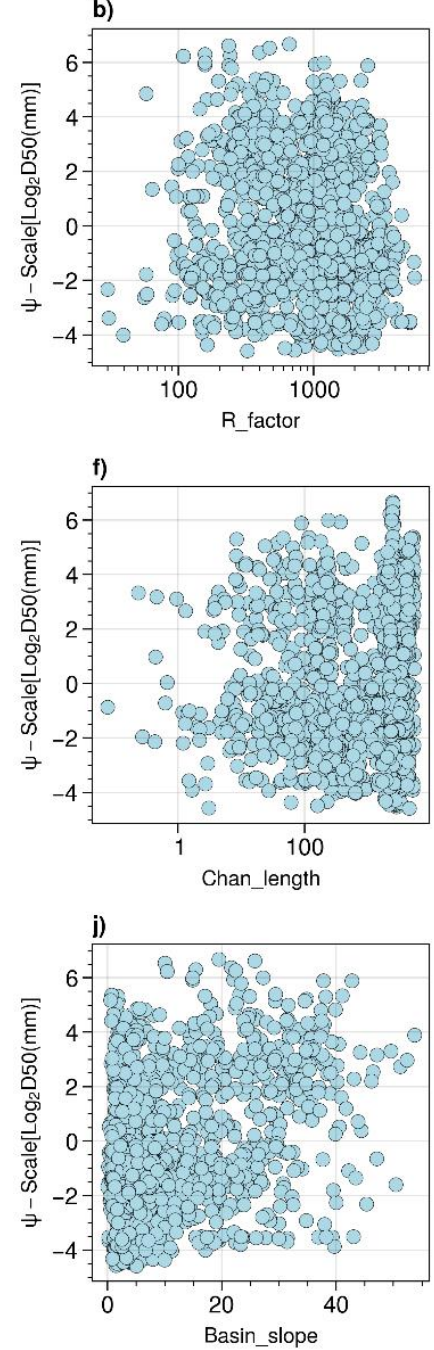
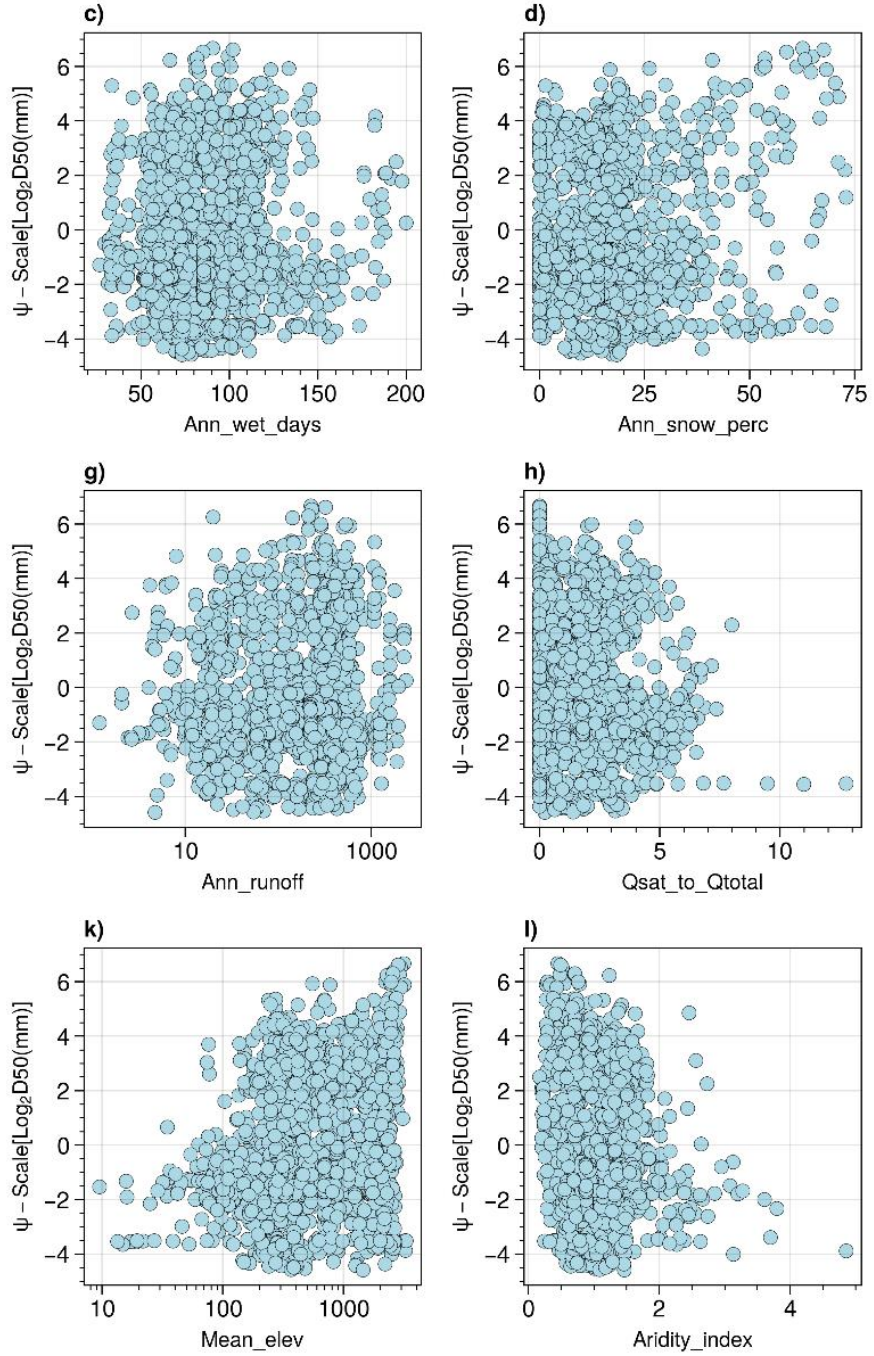

Figure S5. Scatter plots between D50 and the selected 13 features 

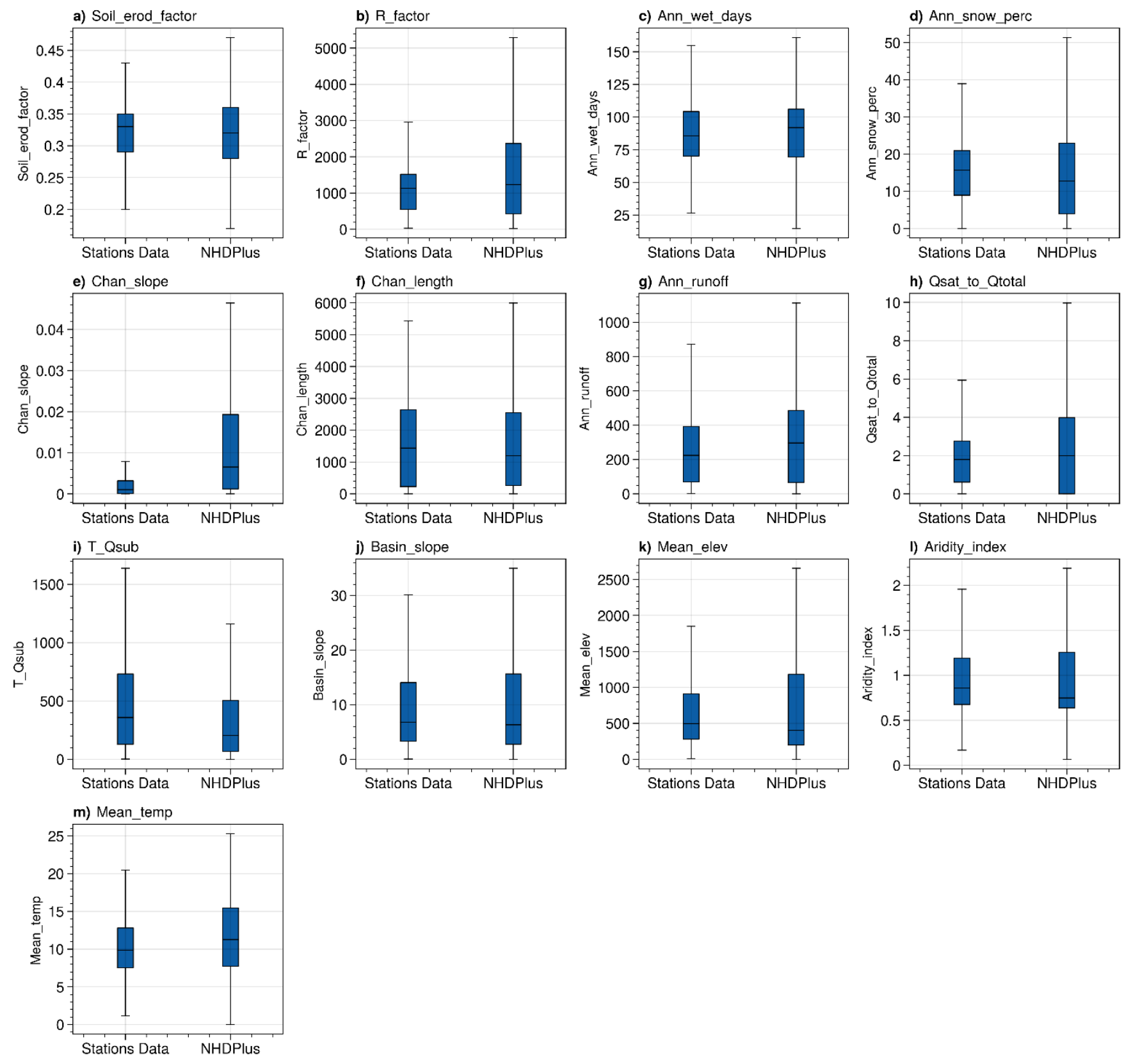

Figure S6: Box plots for the comparison of the ranges of 13 parameters between stations with measured D50 data and all flowlines (i.e., NHDPlus). 
a) Based on KGE : 12-Features(Training)

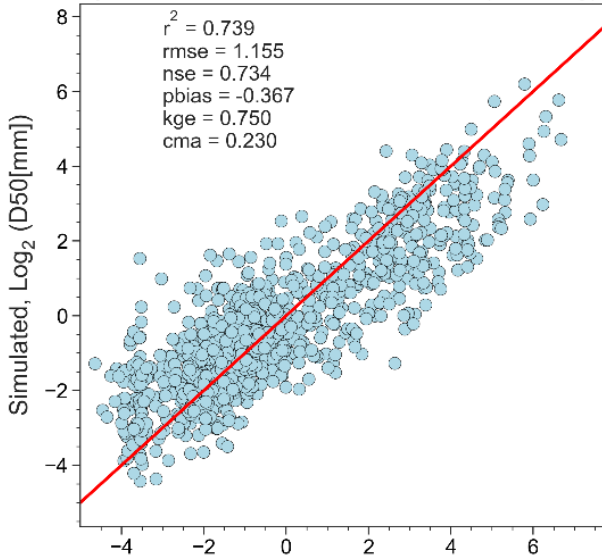

c) Based on NSE : 12 - Features(Training)

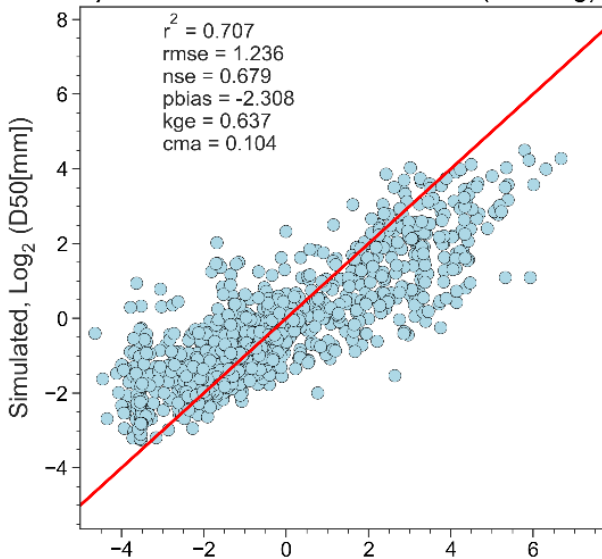

e) Based on $R^{2}$ : 12 - Features(Training)

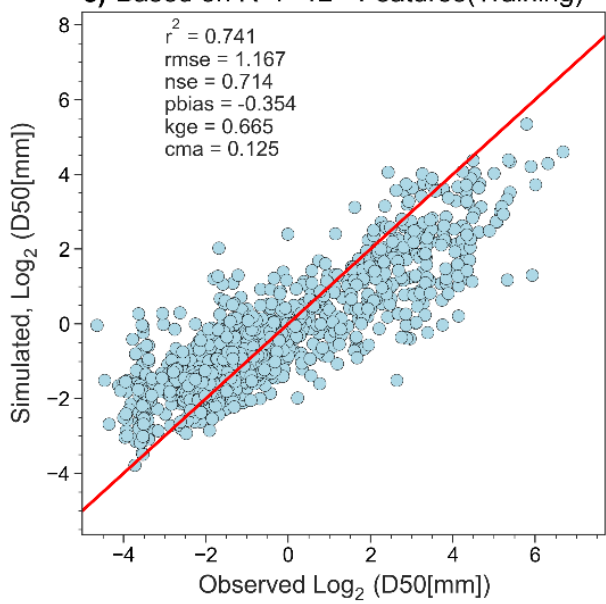

b) Based on KGE : 12 - Features(Test)

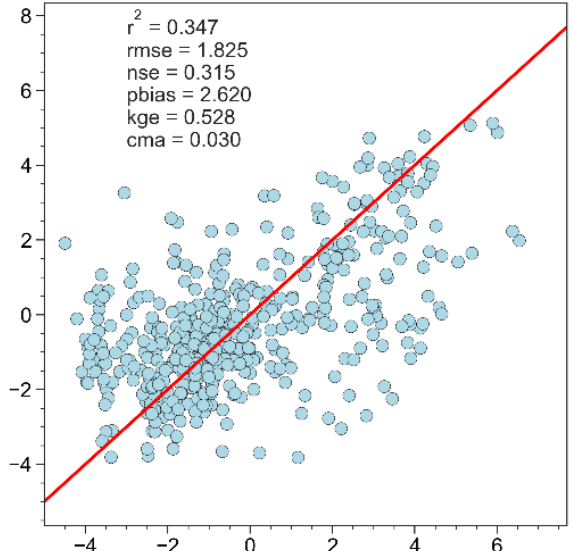

d) Based on NSE : 12 - Features(Test)

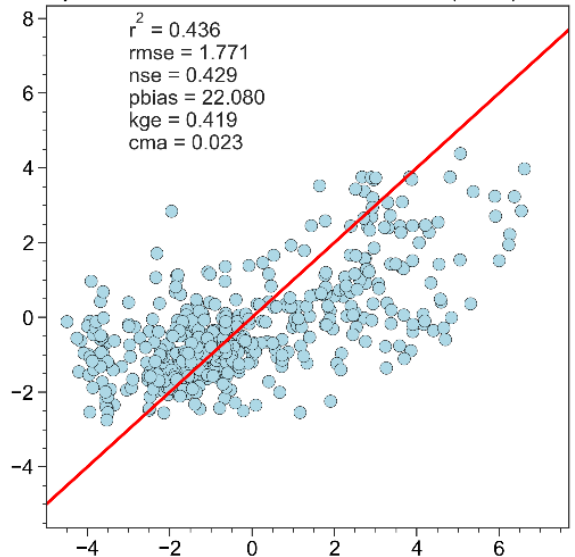

f) Based on $R^{2}$ : $12-$ Features(Test)

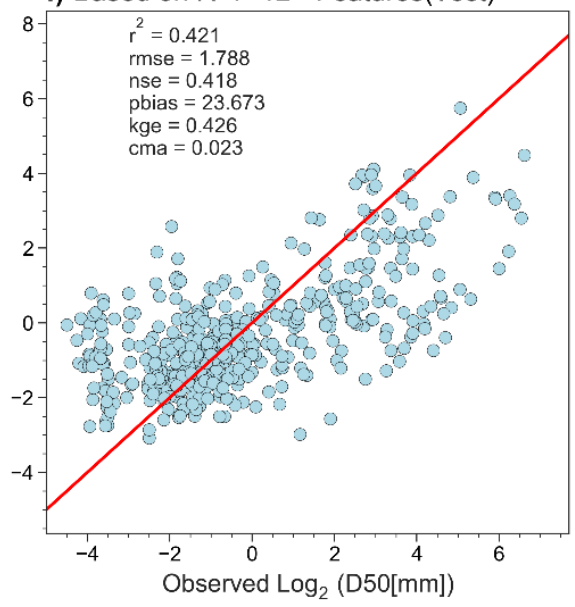

Figure S7: ML modeling using different objective functions 
Table S1: List of the 76 predictive variables

\begin{tabular}{|c|c|c|}
\hline Group & Acronym & Description \\
\hline \multicolumn{3}{|l|}{ Soil } \\
\hline 1 & TOT_SILTAVE & $\begin{array}{l}\text { Accumulated average percent of silt in soil based on total upstream } \\
\text { routing }\end{array}$ \\
\hline 2 & TOT_CLAYAVE & $\begin{array}{l}\text { Accumulated average percent of clay in soil based on total } \\
\text { upstream routing }\end{array}$ \\
\hline 3 & TOT_SANDAVE & Average percent of sand in soil based on total upstream routing \\
\hline 4 & TOT_KFACT & $\begin{array}{l}\text { Accumulated average value for all upstream catchments for } \\
\text { KFactor based on total upstream routing }\end{array}$ \\
\hline 5 & TOT_KFACT_UP & $\begin{array}{l}\text { Average value for KFactor in the upper soil horizon based on total } \\
\text { upstream routing }\end{array}$ \\
\hline 6 & TOT_NO10AVE & $\begin{array}{l}\text { Accumulated average percent by weight of soil material less than } \\
3 \text { inches in size that passes through a No. } 10 \text { sieve ( } 2 \text { millimeters) } \\
\text { based on total upstream routing }\end{array}$ \\
\hline 7 & TOT_NO200AVE & $\begin{array}{l}\text { Accumulated average percent by weight of soil material less than } \\
3 \text { inches in size that passes through a No. } 200 \text { sieve (.074 } \\
\text { millimeters) based on total upstream routing }\end{array}$ \\
\hline 8 & TOT_NO4AVE & $\begin{array}{l}\text { Average percent by weight of soil material less than } 3 \text { inches in } \\
\text { size that passes through a No. } 4 \text { sieve ( } 5 \text { millimeters) based on total } \\
\text { upstream routing }\end{array}$ \\
\hline \multicolumn{3}{|c|}{$\begin{array}{l}\text { Lithology and } \\
\text { Geology }\end{array}$} \\
\hline 1 & TOT_OLSON_K & $\begin{array}{l}\text { Estimated mean accumulated percentage of lithological potassium } \\
\text { oxide (K2O) content in surface or near surface geology of all } \\
\text { upstream NHDPlusV2 catchments }\end{array}$ \\
\hline 2 & TOT_OLSON_CAO & $\begin{array}{l}\text { Estimated mean accumulated percentage of lithological calcium } \\
\text { oxide }(\mathrm{CaO}) \text { content in surface or near surface geology of all } \\
\text { upstream NHDPlusV2 catchments }\end{array}$ \\
\hline 3 & TOT_OLSON_FE & $\begin{array}{l}\text { Estimated mean accumulated percentage of lithological ferric } \\
\text { oxide (Fe2O3) content in surface or near surface geology of all } \\
\text { upstream NHDPlusV2 catchments }\end{array}$ \\
\hline
\end{tabular}




\begin{tabular}{|c|c|c|}
\hline 4 & TOT_OLSON_MGO & $\begin{array}{l}\text { Estimated mean accumulated percentage of catchment that } \\
\text { contains by the Olson geology of type rock type, Carbonate-rock } \\
\text { aquifers. }\end{array}$ \\
\hline 5 & TOT_OLSON_P & $\begin{array}{l}\text { Estimated mean accumulated percentage of catchment that } \\
\text { contains lithological phosphorus pentoxide (P2O5) content in } \\
\text { surface or near surface geology of all upstream NHDPlusV2 } \\
\text { catchments }\end{array}$ \\
\hline 6 & TOT_OLSON_S & $\begin{array}{l}\text { Estimated mean accumulated percentage of lithological sulfur (S) } \\
\text { content in surface or near surface geology of all upstream } \\
\text { NHDPlusV2 catchments }\end{array}$ \\
\hline 7 & TOT_OLSON_SI & $\begin{array}{l}\text { Estimated mean accumulated percentage of lithological silicon } \\
\text { dioxide ( } \mathrm{SiO} 2) \text { content in surface or near surface geology of all } \\
\text { upstream NHDPlusV2 catchments }\end{array}$ \\
\hline 8 & TOT_OLSON_UCS & $\begin{array}{l}\text { Estimated mean accumulated lithological compressive strength, } \\
\text { measured as uniaxial compressive strength (in megaPascals, MPa) } \\
\text { of surface or near surface geology of all upstream NHDPlusV2 } \\
\text { catchments }\end{array}$ \\
\hline 9 & TOT_OLSON_PERM & $\begin{array}{l}\text { Estimated mean accumulated percentage of lithological hydraulic } \\
\text { conductivity (in micrometers per second) of surface or near surface } \\
\text { geology of all upstream NHDPlusV2 catchments }\end{array}$ \\
\hline 10 & CARB & $\begin{array}{l}\text { Estimated percent of the catchment covered by Carbonate rocks } \\
\text { such as limestone and dolostone }\end{array}$ \\
\hline 11 & CLAST_C & $\begin{array}{l}\text { Estimated percent of the catchment covered by Clastic } \\
\text { sediments/rocks primarily made of sands, gravels, cobles, or larger } \\
\text { clasts. }\end{array}$ \\
\hline 12 & CLAST_F & $\begin{array}{l}\text { Estimated percent of the catchment covered by Clastic } \\
\text { sediments/rocks primarily made of fine-grained materials such as } \\
\text { shale, siltstone, claystone, mudstone. }\end{array}$ \\
\hline 13 & CLAST_U & $\begin{array}{l}\text { Estimated percent of the catchment covered by Clastic } \\
\text { sediments/rocks of unknown or highly variable clast sizes }\end{array}$ \\
\hline 14 & EVAP & $\begin{array}{l}\text { Estimated percent of the catchment covered by Evaporites or } \\
\text { playas. }\end{array}$ \\
\hline
\end{tabular}




\begin{tabular}{|c|c|c|}
\hline 15 & META & $\begin{array}{l}\text { Estimated percent of the catchment covered by Metamorphic } \\
\text { rocks. }\end{array}$ \\
\hline 16 & PLUT_OTH & $\begin{array}{l}\text { Estimated percent of the catchment covered by Igneous, generally } \\
\text { mafic, other less quartz-rich plutonic rocks, such as monzonite or } \\
\text { gabbro. }\end{array}$ \\
\hline 17 & PLUT_QTZ & $\begin{array}{l}\text { Estimated percent of the catchment covered by Igneous, generally } \\
\text { felsic, quartz-rich plutonic rocks such as granitoids, granite, } \\
\text { granodacite. }\end{array}$ \\
\hline 18 & VOLC_OTH & $\begin{array}{l}\text { Estimated percent of the catchment covered by Igneous, generally } \\
\text { mafic, volcanic rocks, such as basalt that are mineralogically } \\
\text { equivalent to the less quartz-rich plutonic rocks }\end{array}$ \\
\hline 19 & VOLC_QTZ & $\begin{array}{l}\text { Estimated percent of the catchment covered by Igneous, generally } \\
\text { felsic, volcanic rocks such as rhyolite and dacite that are } \\
\text { mineralogically equivalent to the quartz-rich plutonic rocks }\end{array}$ \\
\hline 20 & WATER & Estimated percent of the catchment covered by Water or ice. \\
\hline \multicolumn{3}{|c|}{ Topography } \\
\hline 1 & BANKFULL_WIDTH & $\begin{array}{l}\text { Estimated bankfull width of flowline reach calculated using Bieger } \\
\text { 's regression equation (Bieger et al, 2015) }\end{array}$ \\
\hline 2 & BANKFULL_DEPTH & $\begin{array}{l}\text { Estimated bankfull depth of flowline reach calculated using } \\
\text { Bieger 's regression equation (Bieger et al, 2015) }\end{array}$ \\
\hline 3 & $\begin{array}{l}\text { BANKFULL_XSEC_AR } \\
\text { EA }\end{array}$ & $\begin{array}{l}\text { Estimated bankfull cross sectional area of flowline reach } \\
\text { calculated using Bieger 's regression equation (Bieger et al, 2015) }\end{array}$ \\
\hline 4 & sinuosity & Flowline reach sinuosity at the flowline reach scale only \\
\hline 5 & TOT_BASIN_SLOPE & Average slope in percent of all upstream flowline catchments \\
\hline 6 & TOT_ELEV_MEAN & Mean elevation in meters of all upstream flowline catchments \\
\hline 7 & TOT_STREAM_SLOPE & Average slope in percent flowlines \\
\hline 8 & $\begin{array}{l}\text { TOT_STREAM_LENGT } \\
\mathrm{H}\end{array}$ & Total length of all upstream flowlines in kilometers \\
\hline \multicolumn{3}{|c|}{ Climate } \\
\hline 1 & TOT_RF7100 & $\begin{array}{l}\text { Accumulated estimated watershed mean annual average for the } \\
\text { Rainfall and Runoff factor ("R factor" of Universal Soil Loss } \\
\text { Equation) for the period 1971-2000 in hundreds of foot-ton force- } \\
\text { inch/acre-hour per year for the period 1971-2000 }\end{array}$ \\
\hline
\end{tabular}




\begin{tabular}{|c|c|c|}
\hline 2 & TOT_WDANN & $\begin{array}{l}\text { Accumulated value for all upstream catchments for the annual } 30 \\
\text { year average (1961-1990) number of days of measurable } \\
\text { precipitation }\end{array}$ \\
\hline 3 & TOT_PRSNOW & $\begin{array}{l}\text { Accumulated estimated mean annual snow as a percent of total } \\
\text { precipitation, } 1905-2002\end{array}$ \\
\hline 4 & AI & Aridity Index \\
\hline 5 & TOT_Temprature & Accumulated annual value of temperature \\
\hline 6 & TOT_RFACT & $\mathrm{R}$ factor of Universal Soil Loss Equation \\
\hline \multicolumn{3}{|c|}{ NHDPlus } \\
\hline 1 & lengthkm & Flowline length in kilometers \\
\hline 2 & streamorde & stream order \\
\hline 3 & totdasqkm & Drainage area in square kilometers \\
\hline 4 & maxelevsmo & maximum elevation of flowline \\
\hline 5 & minelevsmo & minmum elevation of flowline \\
\hline 6 & slope & Flowline slope \\
\hline 7 & ve_ma & flow velocity \\
\hline 8 & pathlength & Flowline distance from the basin outlet( termnial outlet) \\
\hline \multicolumn{3}{|c|}{ Hydrology } \\
\hline 1 & TOT_RUN7100 & $\begin{array}{l}\text { Accumulated estimated 30-year (1971-2000) average annual } \\
\text { runoff, mm/year based on total upstream accumulation }\end{array}$ \\
\hline 2 & TOT_STRM_DENS & $\begin{array}{l}\text { Density of streams defined as stream length (meters) divided by } \\
\text { catchment(s) area (square meters). }\end{array}$ \\
\hline 3 & TOT_HLR_1 & $\begin{array}{l}\text { Accumulated estimated percent of catchment that contains } \\
\text { subhumid plains with permeable soils and bedrock }\end{array}$ \\
\hline 4 & TOT_HLR_2 & $\begin{array}{l}\text { Accumulated estimated percent of catchment that contains humid } \\
\text { plains with permeable soils and bedrock }\end{array}$ \\
\hline 5 & TOT_HLR_3 & $\begin{array}{l}\text { Accumulated estimated percent of catchment that contains } \\
\text { subhumid plains with impermeable soils and permeable bedrock }\end{array}$ \\
\hline 6 & TOT_HLR_4 & $\begin{array}{l}\text { Accumulated estimated percent of catchment that contains humid } \\
\text { plains with permeable soils and bedrock }\end{array}$ \\
\hline 7 & TOT_HLR_5 & $\begin{array}{l}\text { Accumulated estimated percent of catchment that contains arid } \\
\text { plains with permeable soils and bedrock }\end{array}$ \\
\hline
\end{tabular}




\begin{tabular}{|c|c|c|}
\hline 8 & TOT_HLR_6 & $\begin{array}{l}\text { Accumulated estimated percent of catchment that contains } \\
\text { subhumid plains with impermeable soils and bedrock }\end{array}$ \\
\hline 9 & TOT_HLR_7 & $\begin{array}{l}\text { Accumulated estimated percent of catchment that contains humid } \\
\text { plains with permeable soils and impermeable bedrock }\end{array}$ \\
\hline 10 & TOT_HLR_8 & $\begin{array}{l}\text { Accumulated estimated percent of catchment that contains semi } \\
\text { arid plains with impermeable soils and bedrock }\end{array}$ \\
\hline 11 & TOT_HLR_9 & $\begin{array}{l}\text { Accumulated estimated percent of catchment that contains humid } \\
\text { plateaus with impermeable soils and permeable bedrock }\end{array}$ \\
\hline 12 & TOT_HLR_10 & $\begin{array}{l}\text { Accumulated estimated percent of catchment that contains arid } \\
\text { plateaus with impermeable soils and permeable bedrock }\end{array}$ \\
\hline 13 & TOT_HLR_11 & $\begin{array}{l}\text { Accumulated estimated percent of catchment that contains humid } \\
\text { plateaus with impermeable soils and bedrock }\end{array}$ \\
\hline 14 & TOT_HLR_12 & $\begin{array}{l}\text { Accumulated estimated percent of catchment that contains semi } \\
\text { arid plateaus with permeable soils and impermeable bedrock }\end{array}$ \\
\hline 15 & TOT_HLR_13 & $\begin{array}{l}\text { Accumulated estimated percent of catchment that contains semi } \\
\text { arid plateaus with impermeable soils and bedrock }\end{array}$ \\
\hline 16 & TOT_HLR_14 & $\begin{array}{l}\text { Accumulated estimated percent of catchment that contains arid } \\
\text { playas with permeable soils and bedrock }\end{array}$ \\
\hline 17 & TOT_HLR_15 & $\begin{array}{l}\text { Accumulated estimated percent of catchment that contains semi } \\
\text { arid mountains with impermeable soils and permeable bedrock }\end{array}$ \\
\hline 18 & TOT_HLR_16 & $\begin{array}{l}\text { Accumulated estimated percent of catchment that contains humid } \\
\text { mountains with permeable soils and impermeable bedrock }\end{array}$ \\
\hline 19 & TOT_HLR_17 & $\begin{array}{l}\text { Accumulated estimated percent of catchment that contains semi } \\
\text { arid mountains with impermeable soils and bedrock }\end{array}$ \\
\hline 20 & TOT_HLR_18 & $\begin{array}{l}\text { Accumulated estimated percent of catchment that contains semi } \\
\text { arid mountains with permeable soils and impermeable bedrock }\end{array}$ \\
\hline 21 & TOT_HLR_19 & $\begin{array}{l}\text { Accumulated estimated percent of catchment that contains very } \\
\text { humid mountains with permeable soils and impermeable bedrock }\end{array}$ \\
\hline 22 & TOT_HLR_20 & $\begin{array}{l}\text { Accumulated estimated percent of catchment that contains humid } \\
\text { mountains with permeable soils and impermeable bedrock }\end{array}$ \\
\hline 23 & TOT_SATOF & $\begin{array}{l}\text { Accumulated mean saturation overland flow as a percent of } \\
\text { streamflow based on total upstream accumulation }\end{array}$ \\
\hline
\end{tabular}




\begin{tabular}{|l|l|l|}
\hline 24 & TOT_IEOF & $\begin{array}{l}\text { Accumulated mean infiltration-excess overland flow as a percent } \\
\text { of streamflow based on total upstream accumulation }\end{array}$ \\
\hline 25 & TOT_TWI & $\begin{array}{l}\text { Accumulated average topgraphic wetness index based on total } \\
\text { upstream accumulation }\end{array}$ \\
\hline 26 & TOT_CONTACT & $\begin{array}{l}\text { Accumulated contact time, the length of time it takes for water to } \\
\text { drain along subsurface flow paths to the stream, based on total } \\
\text { upstream accumulation }\end{array}$ \\
\hline
\end{tabular}

